\title{
SAPS III or APACHE IV: Which score to choose for acute trauma patients in intensive care unit?
}

\author{
Melike Korkmaz Toker, M.D., ${ }^{1}$ ๑ Aykan Gülleroğlu, M.D., ${ }^{2} \odot$ Ayşe Gül Karabay, M.D., ${ }^{3}$ \\ (ㄷ) İlhan Güney Biçer, M.D., ${ }^{4}$ (ㅇ Yavuz Demiraran, M.D. ${ }^{5}$
}

\begin{abstract}
${ }^{1}$ Department of Anesthesiology and Reanimation, Muğla Sıtkı Koçman University Training and Research Hospital, Muğla-Turkey 2Department of Anesthesiology and Intensive Care Unit, Başkent University Ankara Hospital, Ankara-Turkey

${ }^{3}$ Department of Anesthesiology, Ota-Jine Med Private Hospital, İstanbul-Turkey

${ }^{4}$ Department of Anesthesiology and Reanimation, Osmaniye State Hospital, Osmaniye-Turkey

${ }^{5}$ Department of Anesthesiology and Reanimation, Medipol University Faculty of Medicine, İstanbul-Turkey
\end{abstract}

\begin{abstract}
BACKGROUND: The aim of the present study was to evaluate the effectiveness of the Simplified Acute Physiology Score (SAPS) III and the Acute Physiology and Chronic Health Evaluation (APACHE) IV in the prediction of in-hospital mortality in surviving multitrauma patients.

METHODS: This study was conducted in the 13-bed intensive care unit (ICU) of a tertiary hospital. A retrospective review of multitrauma patients whose care was managed in the ICU was performed. Data collection included details of age, gender, ICU admission, and outcome. APACHE IV and SAPS III scores, as well as the predicted mortality rate (PMR), were calculated using web-based calculators.

RESULTS: Of the 90 patients $20 \%(n=18)$ were female and $80 \%(n=72)$ were male. The overall mortality rate was $25.6 \%$. The mean APACHE IV, Acute Physiology Score (APS) and SAPS III score was 69.27 $\pm 34.51,66.42 \pm 33.72$, and 26.36 \pm 27.14 , respectively. The mean PMR according to the APACHE IV and the SAPS III was $26.36 \pm 27.14$ and I7.07 \pm 24.88 , respectively. The area under the curve result of receiver operating characteristic curve analysis was 0.87 for the APACHE IV and 0.93 for the SAPS III.
\end{abstract}

CONCLUSION: The performance of the SAPS III was more sensitive and discriminative than the APACHE IV scoring system for multi-trauma ICU patients.

Keywords: Acute Physiology and Chronic Health Evaluation IV; intensive care unit; mortality; scoring systems; Simplified Acute Physiology Score III; trauma.

\section{INTRODUCTION}

Trauma is one of the world's leading causes of death and disability. ${ }^{[I]}$ The in-hospital mortality rate of trauma patients in Europe ranges between $15 \%$ and $17 \% .{ }^{[2]}$ Following the initial, immediate care provided in the emergency department or operating theater, patients with severe trauma need a close evaluation to determine treatment and further management in the intensive care unit (ICU). Management in the ICU includes predicting survival using severity scores. The estimation of mortality in trauma patients is important in order to determine and address factors that prolong hospitalization. According to the data of the German Trauma Annual Registry Report System, the average duration of stay in the ICU after severe trauma was 8 days. ${ }^{[3]}$

A number of scoring systems have been developed for critically ill patients. These include the. Acute Physiology and Chronic Health Evaluation (APACHE) score and the Simplified Acute Physiology Score (SAPS) models, which are widely used to assess the severity of illness and perform outcome predictions in critically ill patients.

Cite this article as: Korkmaz Toker M, Gülleroğlu A, Karabay AG, Biçer İG, Demiraran Y. SAPS III or APACHE IV: Which score to choose for acute trauma patients in intensive care unit?. Ulus Travma Acil Cerrahi Derg 2019;25:247-252.

Address for correspondence: Melike Korkmaz Toker, M.D.

Muğla Sıtkı Koçman Üniversitesi Eğitim ve Araştırma Hast., Anesteziyoloji ve Reanimasyon Anabilim Dalı, Muğla, Turkey

Tel: +90 252 - 2141323 E-mail: meltoker@gmail.com 
The APACHE-IV, the most recent version, is calculated based on 129 variables derived within the first 24 hours of ICU admission, and was developed based on 110,588 patients admitted to more than 104 ICUs across the US. ${ }^{[4]}$ The SAPS III was created in 2005 using a database of 16,784 patients from 303 ICUs in 35 countries. ${ }^{[5]}$

Several studies have compared the different outcomes of prediction scoring systems. ${ }^{[6,7]}$ The latest ICU scoring systems, the SAPS III and the APACHE IV are powerful and have benefited from multiple revisions. ${ }^{[5]}$ Although they were determined using several groups of ICU patients, these models have never been designed specifically for multi-trauma patients. Patients with traumatic injuries are typically evaluated with the commonly used scoring systems. ${ }^{[8]}$ Initial arrival trauma scoring systems, such as the Injury Severity Score, the New Injury Severity Score, the Revised Trauma Score, and the Trauma Revised Injury Severity Score have been studied. [9-11] Orhon et al. ${ }^{[10]}$ remarked upon the difficulty of determining an adequate prognosis with only anatomical and physiological injury scores. Nonetheless, the application of severity scoring systems to trauma patients facilitates the evaluation of likely clinical outcomes and the effectiveness of care in multi-trauma patients in the ICU. Both the APACHE and the SAPS tools are logistic regression models that include physiological and laboratory parameters.

To our knowledge, no study has been conducted to evaluate the accuracy of the APACHE-IV and the SAPS III to predict in-hospital mortality in multi-trauma patients in Turkey. The objective of this study was to evaluate and compare the mortality assessment in multi-trauma patients in the ICU predicted by the APACHE IV and the SAPS III scoring systems.

\section{MATERIALS AND METHODS}

Approval for this retrospective cohort research was granted by Istanbul Kanuni Sultan Suleyman Training and Research Hospital Clinical Research Ethical Committee. This study was conducted at the I3 bed ICU at Istanbul Kanuni Sultan Suleyman Training and Research Hospital, Turkey. The retrospective data of multi-trauma patients treated in the ICU between 2013 and 2015 were reviewed. Data collection included patient age, gender, ICU length of stay, and ICU admission and outcome. The APACHE IV, Acute Physiology Score (APS), and SAPS III scores and predicted mortality rate (PMR) were calculated using web-based calculators: http://intensivecarenetwork.com/ Calculators/Files/APACHE4.html and http://intensivecarenetwork.com/Calculators/Files/SAPS3.html. Patients younger than 18 years of age, readmissions to the ICU, burn patients, and patients with insufficient data were excluded from this study.

\section{Statistical Analysis}

NCSS 2007 and PASS 2008 statistical software (NCSS, LLC, Kaysville, UT, USA) were used to perform the statistical analysis. The descriptive data of the study were specified as mean, SD, median, frequency, rate, minimum, and maximum. Mean tests were compared using an independent t-test if the data distribution was normal or the nonparametric MannWhitney $U$ test if the data were not distributed normally. Spearman's correlation analysis was performed to evaluate inter-parameter relationships. Diagnostic screening tests (sensitivity, specificity, positive predictive value, negative predictive value) and receiver operating characteristic (ROC) curve analysis were used to determine the cutoff for the parameters. The $p$ values of $<0.01$ and $<0.05$ were considered statistically significant.

Sample size was calculated based on data from a pilot group of 15 trauma patients. These patients were not included in the main study. In this pilot study, the mean PMR of patients was $29 \pm 22.6$ according to the APACHE IV and $23 \pm 26.8$ according to the SAPS III. Data from 80 patients were required to determine a significant difference with a one-sided type I error $(\alpha)$ of 0.1 and a power $(I-\beta)$ of 0.7 . An additional 10 patients were added to compensate for dropouts; a total of 90 patients were enrolled.

\section{RESULTS}

The study was conducted with 90 multi-trauma patients who were admitted to the ICU between January 2013 and February 2015. Of the 90 patients, $20 \%(n=18)$ were female and $80 \%$ $(n=72)$ were male. The mean patient age was $38.83 \pm 18.67$ years. The overall mortality rate was $25.6 \%(n=23)$. In all, $63.3 \%(n=57)$ of the patients were transferred to general surgery or neurosurgery wards after ICU treatment and II.I\% $(n=10)$ were referred to other hospitals (Table I). Ten patients referred to other hospitals were subsequently followed up and included in the analysis. All of the patients who were referred survived.

The mean APACHE IV, APS, and SAPS III scores, calculated within 24 hours of admission to the ICU, were $69.27 \pm 34.5 \mathrm{I}$,

Table I. Characteristics of the study group on admission and during follow-up

\begin{tabular}{lllll}
\hline & n & $\%$ & Min-Max & Mean \pm SD \\
\hline $\begin{array}{l}\text { Age (years) } \\
\text { Gender }\end{array}$ & & & $18-92$ & $38.83 \pm 18.67$ \\
$\quad$ Female & 18 & 20.0 & \\
$\quad$ Male & 72 & 80.0 \\
$\begin{array}{l}\text { Patient outcome } \\
\quad \text { Exitus }\end{array}$ & 23 & 25.6 \\
$\quad \begin{array}{l}\text { Discharge to ward } \\
\text { Referred to another hospital }\end{array}$ & 10 & 11.1
\end{tabular}

Min: Minimum; Max: Maximum; SD: Standard deviation. 
Table 2. Distribution of APACHE IV, APS, and SAPS III scores

\begin{tabular}{lcc}
\hline & Min-Max & Mean \pm SD \\
\hline APACHE IV & $21-173$ & $69.27 \pm 34.5 I$ \\
APS & $21-173$ & $66.42 \pm 33.72$ \\
SAPS III & $13-92$ & $42.18 \pm 19.96$ \\
PMR according to APACHE IV & $0.70-94.10$ & $26.36 \pm 27.14$ \\
PMR according to SAPS & $0-86$ & $17.07 \pm 24.88$
\end{tabular}

APACHE: Acute Physiology and Chronic Health Evaluation; APS: Acute Physiology Score; PMR: Predicted mortality rate; SAPS: Simplified Acute Physiology Score.; Min: Minimum; Max: Maximum; SD: Standard deviation.
66.42 \pm 33.72 , and $26.36 \pm 27.14$, respectively. The mean PMR according to the APACHE IV and SAPS III was $26.36 \pm 27.14$ and $17.07 \pm 24.88$, respectively (Table 2 ).

The APACHE IV, APS, and SAPS III scores were significantly different with respect to patient outcome $(p<0.01)$. The PMR according to the APACHE IV and SAPS III was statistically significant $(p<0.01)$ (Table 3).

Analysis of the APACHE IV scores according to mortality revealed a statistically significant difference $(p<0.01)$. The SAPS III mortality scores were also statistically significant $(p<0.0 I)$ (Table 4).

Table 3. APACHE IV, APS, and SAPS III scores according to patient outcome and PMR

\begin{tabular}{|c|c|c|c|c|c|}
\hline & & $\begin{array}{l}\text { Exitus } \\
(n=23)\end{array}$ & $\begin{array}{c}\text { Discharge } \\
(n=57)\end{array}$ & $\begin{array}{c}\text { Referral } \\
(n=10)\end{array}$ & ${ }^{\alpha} \mathbf{p}$ \\
\hline \multirow[t]{2}{*}{ APACHE IV } & Mean $\pm S D$ & $106.09 \pm 38.55$ & $51.04 \pm 15.83$ & $88.50 \pm 24.60$ & $<0.01^{* *}$ \\
\hline & Min-Max (Median) & $47-173(109)$ & $21-99(52)$ & $52-133(92)$ & \\
\hline \multirow[t]{2}{*}{ APS } & Mean $\pm S D$ & $100.83 \pm 38.66$ & $48.75 \pm 15.35$ & $88.00 \pm 24.64$ & $<0.01^{*+1}$ \\
\hline & Min-Max (Median) & $45-173(101)$ & $21-99(49)$ & $52-133(89.50)$ & \\
\hline \multirow[t]{2}{*}{ SAPS III } & Mean $\pm S D$ & $65.87 \pm 17.54$ & $30.30 \pm 8.98$ & $55.40 \pm 12.75$ & $<0.01^{* *}$ \\
\hline & Min-Max (Median) & $36-92(6 I)$ & $13-49(30)$ & $33-73(54)$ & \\
\hline \multirow[t]{2}{*}{ APACHE IV PMR } & Mean \pm SD & $58.22 \pm 28.37$ & $11.37 \pm 11.18$ & $38.50 \pm 18.93$ & $<0.0 I^{*+2}$ \\
\hline & Min-Max (Median) & $8.4-94.1$ (67.5) & $0.7-48.0(6.9)$ & 10.9-66.1 (39.8) & \\
\hline \multirow[t]{2}{*}{ SAPS III PMR } & Mean \pm SD & $45.48 \pm 29.64$ & $3.25 \pm 3.90$ & $30.50 \pm 20.18$ & $<0.01^{*+1}$ \\
\hline & Min-Max (Median) & $4-86(38)$ & $0-16(2)$ & $3-62(24)$ & \\
\hline
\end{tabular}

$\alpha$ Kruskal-Wallis test. **P<0.0I. APACHE: Acute Physiology and Chronic Health Evaluation; APS: Acute Physiology Score; PMR: Predicted mortality rate; SAPS: Simplified Acute Physiology Score.; Min: Minimum; Max: Maximum; SD: Standard deviation.

Table 4. APACHE IV and SAPS III scores according to mortality

\begin{tabular}{|c|c|c|c|}
\hline & No mortality $(n=67)$ & Mortality $(n=23)$ & $\mathbf{p}$ \\
\hline & Mean $\pm S D$ (Median) & Mean $\pm S D$ (Median) & \\
\hline Acute Physiology and Chronic Health Evaluation IV & $56.63 \pm 21.82(55.00)$ & $106.09 \pm 38.55(109.00)$ & $<0.01^{* *}$ \\
\hline Simplified Acute Physiology Score III & $34.05 \pm 13.11(33.00)$ & $65.87 \pm 17.54(61.00)$ & $<0.01^{* *}$ \\
\hline
\end{tabular}

'Mann-Whitney U Test. " $P<0.01$. APACHE: Acute Physiology and Chronic Health Evaluation; SAPS: Simplified Acute Physiology Score; SD: Standard deviation.

Table 5. Diagnostic scanning tests and ROC curve results for PMR

\begin{tabular}{|c|c|c|c|c|c|c|c|c|}
\hline & \multicolumn{5}{|c|}{ Diagnostic scan } & \multicolumn{2}{|c|}{ ROC curve } & \multirow[t]{2}{*}{$\mathbf{p}$} \\
\hline & Cut-off & Sensitivity & Specificity & $\begin{array}{c}\text { Positive predictive } \\
\text { value }\end{array}$ & $\begin{array}{c}\text { Negative predictive } \\
\text { value }\end{array}$ & Area & $\begin{array}{l}95 \% \text { confidence } \\
\text { interval }\end{array}$ & \\
\hline APACHE IV & 95 & 69.57 & 91.04 & 72.73 & 89.71 & 0.870 & $0.782-0.959$ & $<0.01^{* *}$ \\
\hline SAPS III & 45 & 91.30 & 80.60 & 61.76 & 96.43 & 0.933 & $0.882-0.984$ & $<0.01^{\text {** }}$ \\
\hline
\end{tabular}


ROC analysis and diagnostic scanning tests were used to calculate cutoff points for the APACHE IV and SAPS III prediction of mortality. The data obtained for the APACHE IV were a cutoff value of 95 , with a sensitivity of $69.57 \%$, specificity of $91.04 \%$, positive predictive value of 72.73 , and negative predictive value $89.7 \mathrm{I}$. The cutoff point for the SAPS III score and mortality was 45 , with a sensitivity of $91.30 \%$, specificity of $80.60 \%$, positive predictive value of 61.76 , and a negative predictive value of 96.43 (Table 5). The area under

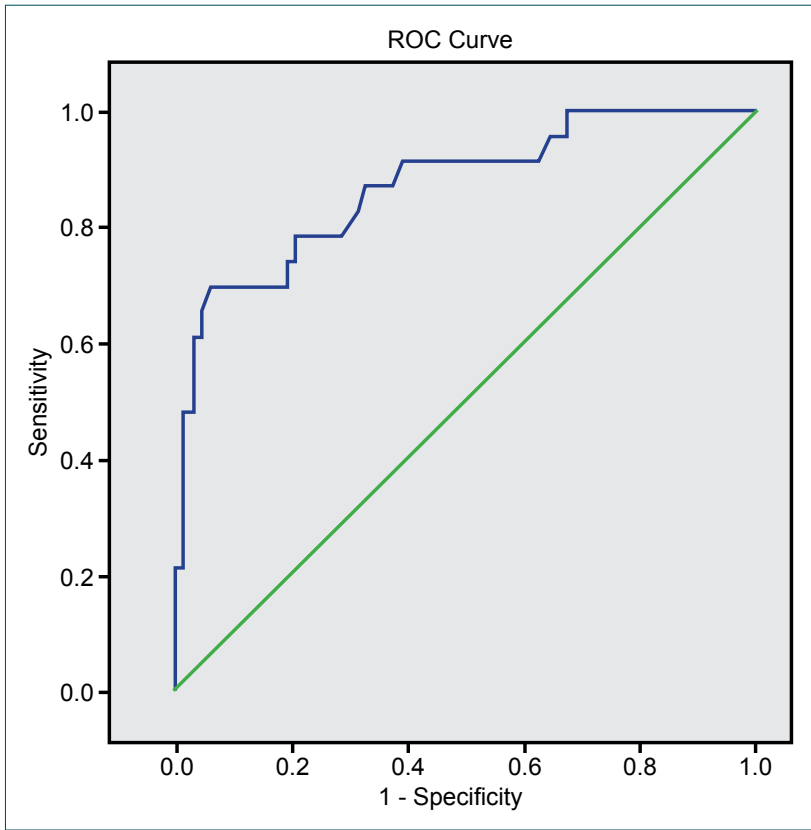

Figure 1. ROC curve graph for APACHE IV score and mortality. APACHE: Acute Physiology and Chronic Health Evaluation; ROC: Receiver operating characteristic.

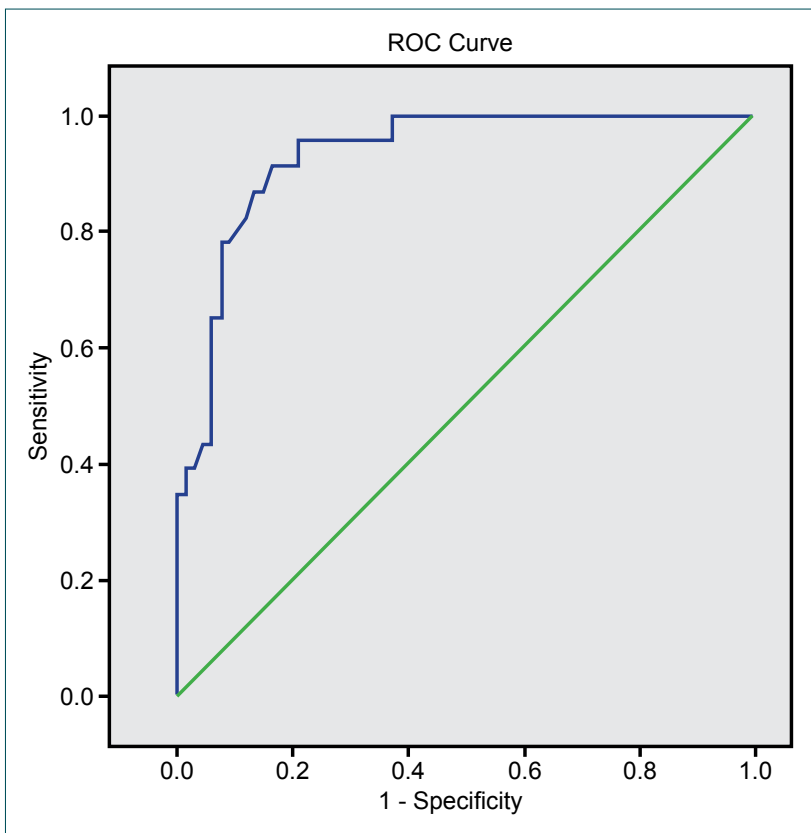

Figure 2. ROC curve graph for SAPS III score and mortality. ROC: Receiver operating characteristic; SAPS: Simplified Acute Physiology Score. the curve (AUC) recorded in the ROC curve graph for the APACHE IV and the SAPS III was $87 \%$ and $93.3 \%$, respectively (Fig. I and Fig. 2).

\section{DISCUSSION}

The results of this study demonstrated that the performance of the SAPS III was more sensitive and discriminative than the APACHE IV score when we evaluated the accuracy of these prediction models for surviving multi-trauma patients in the ICU. Both scoring systems were sufficiently accurate to determine the ICU mortality of trauma patients.

The APACHE II was developed 3 decades ago, in 1985, and became the most commonly used scoring system in ICUs. ${ }^{[4]}$ The advances in quality of care and the emergence of new treatment modalities since then have been immense and have significantly decreased the mortality rate in ICUs, making the older scoring systems more and more inaccurate. ${ }^{[12]}$ The APACHE IV model has been found to have excellent discrimination and calibration in a USA population. ${ }^{[4]}$ Parajuli et al. ${ }^{[12]}$ found that the discrimination of the APACHE IV was better than the APACHE II model. Given the improvements in the APACHE scoring system, we decided to use the APACHE IV instead of the APACHE II in these multi-trauma patients.

In data from Californian ICUs, ${ }^{[7]}$ and Dutch ICUs ${ }^{[13]}$ the overall discrimination of the APACHE IV model was significantly better than the discrimination of the customized SAPS II model. In contrast to the 24-hour time interval used for the SAPS II model, the SAPS III measures the severity of disease based on data recorded within the first hour after admission. [5] The SAPS III score has been shown to exhibit good discrimination, calibration, and goodness of fit. ${ }^{[14]}$ Based on a review of the literature, ${ }^{[7,15]}$ we decided to evaluate the results of the SAPS III against the APACHE IV.

Discrimination is a critical element in the assessment of the reliability of severity scoring systems. It is typically quantified using the AUC. ${ }^{[16]}$ The discrimination of a prognostic model is considered good if the AUC is $>0.8$, moderate if the AUC is between 0.6 and 0.8 , and poor if the AUC is <0.6. ${ }^{[17]}$ Our results for the discrimination of the SAPS III were consistent with previous external validation studies (earlier AUC results: $0.82-0.93) \cdot{ }^{[13,18,19]}$ Our findings were also supported by the results of an external validation study in which APACHE IV models proved to have good overall discrimination and accuracy in Dutch ICUs (AUC: 0.87; Brier score: 0.10). ${ }^{[13]}$

Nassar et al. ${ }^{[19]}$ researched the performance of the APACHE IV, the SAPS III and the Mortality Probability Model in Brazilian ICUs. They reported an AUC of 0.883 for the APACHE IV, while it was 0.855 for the SAPS III. The results of this study were not exactly consistent with our research; however, Nassar et al. used study groups with low-risk patient 
populations due to the absence of intermediate ICU facilities, and differences in the study population, regional variability in end-of-life decisions, and temporal bias, that is, the interval between the development of the prognostic models and study enrollment, may explain some variations.

The observed mortality rate in the present study was $25.6 \%$, and the mortality rate of each prognostic model studied was $26.36 \pm 27.14$ for the APACHE IV and $17.7 \pm 24$ for the SAPS III. All of the prognostic models we were used in our study, were produced a near-complete mortality estimate. accurate

Our results suggest that the SAPS III scoring system was more sensitive to in-hospital mortality prediction than the APACHE IV for surviving trauma patients. The SAPS III admission score was based on records from within the first hour of acceptance of trauma patients to the ICU.[5] Half of the estimated power of earlier versions of the SAPS score is generated by compiling patient data from prior to admission to the ICU. A score recorded after the first 24 hours following ICU admission may in large part reflect the standard of care, rather than actual clinical status. Likely as a result of this advantage, we found the SAPS III score to be more sensitive than the APACHE IV.

Ayazoglu et al. ${ }^{[20]}$ conducted an APACHE IV validation study on a segment of the Turkish population and reported that the APACHE IV scoring system was successful in predicting mortality and evaluating the efficacy of treatment in a cardiovascular-thoracic surgery ICU. Geyik et al. ${ }^{[2]]}$ compared the mortality rate of ICU patients according to the APACHE II and IV scores and found that the APACHE II was superior in predicting mortality. This result may have been a reflection of the consistency of the patient groups in their study. To our knowledge, the present study is the first to compare the APACHE IV and the SAPS III using a Turkish population of trauma patients.

Our study has potential limitations. The first is associated with the retrospective design. Another is that the study was conducted at a single ICU. Due to institutionally related differences in the management of trauma, the assessment of prognostic models from a single institution limits the ability to generalize our results to other ICUs.

In conclusion, the results of our research demonstrated that the discrimination of both the APACHE IV and the SAPS III indicated that they were good tools for the evaluation of trauma patients treated in our ICU. The SAPS III had greater discriminatory power and sensitivity than the APACHE IV in predicting the mortality of multi-trauma patients in the ICU. It is recommended that further studies be performed to validate the SAPS III scoring system in varied ICUs that mostly deal with trauma.

Conflict of interest: None declared.

\section{REFERENCES}

1. Curry N, Hopewell S, Dorée C, Hyde C, Brohi K, Stanworth S. The acute management of trauma hemorrhage: a systematic review of randomized controlled trials. Crit Care 2011;15:R92.

2. Böhmer AB, Just KS, Lefering R, Paffrath T, Bouillon B, Joppich R, et al. Factors influencing lengths of stay in the intensive care unit for survivingtrauma patients: a retrospective analysis of 30,157 cases. Crit Care 2014;18:R143.

3. Lefering R, Nienaber U, Paffrath T. TraumaRegister DGU ${ }^{\otimes}$ of the German Trauma Society. Notf Rett Med 2013;16:269-73.

4. Zimmerman JE, Kramer AA, McNair DS, Malila FM. Acute Physiology and Chronic Health Evaluation (APACHE) IV: hospital mortality assessment for today's critically ill patients. Crit Care Med 2006;34:1297310.

5. Vincent JL, Moreno R. Clinical review: scoring systems in the critically ill. Crit Care 2010;14:207.

6. Livingston BM, MacKirdy FN, Howie JC, Jones R, Norrie JD. Assessment of the performance of five intensive care scoring models within a large Scottish database. Crit Care Med 2000;28:1820-7.

7. Kuzniewicz MW, Vasilevskis EE, Lane R, Dean ML, Trivedi NG, Rennie DJ, et al. Variation in ICU risk-adjusted mortality: impact of methods of assessment and potential confounders. Chest 2008;133:1319-27.

8. Moon SH, Kim JW, Byun JH, Kim SH, Choi JY, Jang IS, et al. The thorax trauma severity score and the trauma and injury severity score: Do they predict in-hospital mortality in patients with severe thoracic trauma?: A retrospective cohort study. Medicine (Baltimore) 2017;96:e8317.

9. Honarmand A, Safavi M. The new Injury Severity Score: a more accurate predictor of need ventilator and time ventilated in trauma patients than the Injury Severity Score. Ulus Travma Acil Cerrahi Derg 2008;14:110-7.

10. Orhon R, Eren SH, Karadayı S, Korkmaz I, Coşkun A, Eren M, et al. Comparison of trauma scores for predicting mortality and morbidity on trauma patients. Ulus Travma Acil Cerrahi Derg 2014;20:258-64.

11. Schluter PJ, Cameron CM, Davey TM, Civil I, Orchard J, Dansey R, et al. Using Trauma Injury Severity Score (TRISS) variables to predict length of hospital stay following trauma in New Zealand. N Z Med J 2009;122:65-78.

12. Parajuli BD, Shrestha GS, Pradhan B, Amatya R. Comparison of acute physiology and chronic health evaluation II and acute physiology and chronic health evaluation IV to predict intensive care unit mortality. Indian J Crit Care Med 2015;19:87-91.

13. Brinkman S, Bakhshi-Raiez F, Abu-Hanna A, de Jonge E, Bosman RJ, Peelen L, et al. External validation of Acute Physiology and Chronic Health Evaluation IV in Dutch intensive care units and comparison with Acute Physiology and ChronicHealth Evaluation II and Simplified Acute Physiology Score II. J Crit Care 2011;26:105.e11-8.

14. Moreno RP, Metnitz PG, Almeida E, Jordan B, Bauer P, Campos RA, et al. SAPS 3--From evaluation of the patient to evaluation of the intensive care unit. Part 2: Development of a prognostic model for hospital mortality at ICU admission. Intensive Care Med 2005;31:1345-55.

15. Khwannimit B, Bhurayanontachai R. The performance and customization of SAPS 3 admission score in a Thaimedical intensive care unit. Intensive Care Med 2010;36:342-6.

16. Frederickson TA, Renner CH, Swegle JR, Sahr SM. The cumulative effect of multiple critical care protocols on length of stay in a geriatric trauma population. J Intensive Care Med 2013;28:58-66.

17. Hernandez AM, Palo JE. Performance of the SAPS 3 admission score as a predictor of ICU mortality in a Philippine private tertiary medical center intensive care unit. J Intensive Care 2014;2:29. 
18. Ledoux D, Canivet JL, Preiser JC, Lefrancq J, Damas P. SAPS 3 admission score: an external validation in a general intensive care population. Intensive Care Med 2008;34:1873-7.

19. Nassar AP Jr, Mocelin AO, Nunes AL, Giannini FP, Brauer L, Andrade FM, et al. Caution when using prognostic models: a prospective comparison of 3 recentprognostic models. J Crit Care 2012;27:423.e1-7.
20. Ayazoglu AT, Candan A, Ozkaynak I EI. Investigation of the effectiveness of the APACHE IV Model for the evaluation of prognosis in the intensive care unit patients. New J Med 2012;29:100-4.

21. Geyik FD, Altun GT, Citak N, Ayazoglu TA. A comparison of APACHE II and APACHE IV scoring systems in patients admitted to an Intensive Care Unit. [Turkish]. Journal of Anesthesia 2013;21:182-6.

\section{ORIJINAL ÇALIŞMA - ÖZET}

\section{Yoğun bakımdaki akut travma hastalarında hangi skoru seçmeliyiz:}

SAPS III mü, APACHE IV mü?

\section{Dr. Melike Korkmaz Toker, ${ }^{1}$ Dr. Aykan Gülleroğlu, ${ }^{2}$ Dr. Ayşe Gül Karabay, ${ }^{3}$ Dr. İlhan Güney Biçer, ${ }^{4}$ Dr. Yavuz Demiraran ${ }^{5}$}

${ }^{1}$ Muğla Sıtkı Koçman Üniversitesi Eğitim ve Araştırma Hastanesi, Anesteziyoloji ve Reanimasyon Anabilim Dalı, Muğla

Başkent Üniversitesi Ankara Hastanesi, Anesteziyoloji ve Yoğun Bakım Anabilim Dalı, Ankara

${ }^{3}$ Ota-Jine Med Hastanesi, Anesteziyoloji Kliniği, İstanbul

${ }^{4}$ Osmaniye Devlet Hastanesi, Anesteziyoloji ve Reanimasyon Kliniği, Osmaniye

${ }^{5}$ Medipol Üniversitesi Tıp Fakültesi, Anesteziyoloji ve Reaniamasyon Anabilim Dalı, İstanbul

AMAÇ: Çalışmanın amacı, hayatta kalan çoklu travma hastalarında basitleştirilmiş akut fizyoloji skoru (SAPS) III ve akut fizyoloji ve kronik sağılık değerlendirmesi (APACHE) IV'ün mortaliteyi öngörmedeki etkinliğini değerlendirmektir.

GEREÇ VE YÖNTEM: Bu çalışma üçüncü basamak bir hastanenin I 3 yataklı yoğun bakım ünitesinde (YBÜ) gerçekleştirildi. YBÜ'de tedavi edilen çoklu travma hastalarının geriye dönük bir incelemesi yapıldı. Toplanan veriler yaş, cinsiyet, yoğun bakım kabul ve yoğun bakımdaki sonuçları içeriyordu. APACHE IV, SAPS III ve öngörülen mortalite oranı web tabanlı bir hesap makinasıyla hesaplandı.

BULGULAR: Doksan hastanın \%20'si $(n=18)$ kadın, \%80'i $(n=72)$ erkekti. Genel mortalite oranı \%25.6 idi. APACHE IV, APS ve SAPS III puan ortalamaları 69.27 \pm 34.5 I, $66.42 \pm 33.72$ ve $26.36 \pm 27.14$ bulundu. APACHE IV ve SAPS III'e göre ortalama öngörülen mortalite oranı $26.36 \pm 27.14$ ve 17.07 \pm 24.88 idi. Eğrinin altındaki alan (EAA) sırasıyla APACHE IV ve SAPS III için 0.87, 0.93 idi.

TARTIŞMA: Çoklu travmalı yoğun bakım hasta grubunda, SAPS II'ün performansı APACHE IV skoruna göre daha hassas ve ayırt edicidir. Anahtar sözcükler: Akut fizyoloji ve kronik sağlık değerlendirmesi IV; basitleştirilmiş akut fizyoloji skoru III; mortalite; skorlama sistemleri; travma; yoğun bakım ünitesi.

Ulus Travma Acil Cerrahi Derg 2019;25(3):247-252 doi: 10.5505/tjtes.2018.22866 